\title{
Treatment of Ammonia in Air Stream by Biotrickling Filter Ming-Shean Chou ${ }^{*}$, Chia-Hsi Wang
}

Institute of Environmental Engineering, National Sun Yat-Sen University, Kaohsiung 80424, Taiwan, ROC.

\begin{abstract}
A pilot-scale reactor, consisting of a set of two-stage-in-series biotrickling filters, an influent gas supply system and a liquid recirculation system, was utilized to treat ammonia in an airstream. Each stage of the biotrickling filter was constructed from a $20 \mathrm{~cm} \times 200 \mathrm{~cm}$ (inner diameter $\times$ height) acrylic column packed with cokes (average diameter $=3.0 \mathrm{~cm}$, specific area $=150 \mathrm{~m}^{2} / \mathrm{m}^{3}$ ) of $125 \mathrm{~cm}$ height. Experimental results indicate that a time of 30 days is required for development of biofilms for nitrification of the absorbed ammonia from the gas. Long-term (187 days) experimental results show that, in the conditions of EBRT (empty bed gas retention time) = $7.25 \mathrm{~s}$, “circulation liquid/gas" flow rate ratio $=7.7 \mathrm{~L} / \mathrm{m}^{3}$, and liquid $\mathrm{pH}=6.65$, the level of ammonia in the influent gas was reduced from 230 to $4.0 \mathrm{ppm}$. With the volumetric ammonia loading of less than $7.37 \mathrm{~g} \mathrm{NH}_{3}-\mathrm{N} / \mathrm{m}^{3}$.h, the system could achieve ammonia removal and nitrification efficiencies of 98 and $94 \%$, respectively, without supplementary glucose as a carbon source. However, with a loading of $13.1 \mathrm{~g} \mathrm{NH}_{3}-\mathrm{N} / \mathrm{m}^{3}$.h, both decreased gradually due to a lack of carbon source and an accumulation of ammonium and nitrite ions in the recirculation liquid.
\end{abstract}

Keywords: Ammonia; Nitrification; Air pollution control; Biotrickling filter.

\footnotetext{
${ }^{*}$ Corresponding author. Tel.: +886-7-5254408, Fax: +886-7-5254449.

E-mail address: ms.chou@msa.hinet.net
} 


\section{INTRODUCTION}

Ammonia is released into the atmosphere from various sources, such as carcass-processing plants, sewage treatment plants, composting works, livestock farms and wastewater treatment plants (Chung et al., 1996; Malhautier et al., 2003). The emission can constitute a source of olfactory nuisance, and lead to nutrient enrichment and acidification of aquatic and terrestrial environments (Scholtens et al., 1987).

Biotreatment of odoriferous contaminants in airstreams provides an inexpensive alternative to conventional technologies, such as catalytic and thermal oxidation, chemical scrubbing, ozonation and activated carbon adsorption (Don and Feenstra, 1984; Ottengraf, 1986). Biofilters and biotrickling filters are currently the most common bioreactors applied in air pollution control.

A biofiltration system mainly consists of a reactor packed with solid material, on which a biolayer containing a proper microbial population is formed. When a contaminated airstream passes through the reactor, the pollutants in the stream are adsorbed by the biolayer, and are then biodegraded by the microorganisms in the biofilm (Don and Feenstra, 1984). The packed solid media provide the nutrient source, $\mathrm{pH}$ buffer and matrix for the attachment of microorganisms. Some biofiltration media, including compost, peat, soil, bark, perlite and activated carbon, have been used to eliminate of ammonia from contaminated airstreams (Hartikainen et al., 1996; Mohamad et al., 1998; Jitendra et al., 2000; Chung et al., 2001; Choi et al., 2003; Liao et al., 2004; Chung et al., 2004; Chung et al., 2005). As indicated in the literature, biofilters have been successfully used to remove ammonia in airstreams. However, biofilters have some unavoidable drawbacks, such as compaction, channeling, filter degradation and accumulation of acidic or alkaline metabolites. Moreover, biofilters generally operate at lower contaminant loadings and gas flow rates in terms of unit packing media volume than other biological treatment systems, such as biotrickling or bioscrubbering systems.

A biotrickling filter system, which is similar to a biofilter, contains packing material, such as wood, ceramics or plastics, and is operated by recirculating of liquid through the packing. A biofilm is developed on the surface of the packing shortly after the start-up of the system. In this system, the nutrients and $\mathrm{pH}$ buffering agents can be easily added to the recirculation liquid stream, and the metabolites can also be easily removed by replacing the recirculation liquid (Togna and Singh, 1994). Therefore, biotrickling filters can avoid the drawbacks associated with biofilters, and are considered as more effective for treating VOCs (Hartmans and Tramper, 1991; Togna and Folsom, 1992; Ergas et al., 1993; Lith et al., 1993). Thus, the number of studies regarding the treatment of gas-stream contaminants by biotrickling filters has increased in recent decades. Target contaminants have included hydrocarbons, oxygenated hydrocarbons, chlorinated hydrocarbons and sulfur compounds. However, little attention appears to have been given to treating $\mathrm{NH}_{3}$ in an airstream by a biotrickling filter. 
This work presents the results of a pilot-scale experiment for the biotrickling treatment of ammonia in an airstream. The experiment used a two-stage biotrickling filter packed with cokes with particle sizes of 20-40 mm and a specific area of $150 \mathrm{~m}^{2} / \mathrm{m}^{3}$. The objectives of this work were to investigate the effects of volumetric loading, EBRT, liquid recirculation rate, and nutrient addition on the removal efficiency and the elimination capacity of ammonia by using the biotrickling filter.

\section{MATERIALS AND METHODS}

\section{Experimental setup}

Fig. 1 shows the experimental setup, consisting of a set of two-stage-in-series biotrickling filters and an influent gas supply system. Each stage of the biotrickling filter was constructed from a $20 \mathrm{~cm} \times 200 \mathrm{~cm}$ (ID $\times \mathrm{H}$ ) acrylic column packed with cokes to a height of $125 \mathrm{~cm}$, and was equipped with a recirculation liquid system holding a total liquid volume of 13 liters. The cokes were provided by the China Steel Corp., Kaohsiung, Taiwan. Table 1 lists the physical and chemical characteristics of the cokes. The cokes are carbon residuals, which are produced mainly from thermal pyrolysis of coal and petroleum. Uses of cokes include as a carbon additive agent, fuel and a reducing agent for iron roasting. They are both chemically and physically stable at ambient temperatures.

Table 1. Properties of the packing material (cokes) for the experimental biotrickling filter.

\begin{tabular}{lc}
\hline \multicolumn{1}{c}{$\begin{array}{c}\text { Item } \\
(1)\end{array}$} & $\begin{array}{c}\text { Value } \\
(2)\end{array}$ \\
\hline Approximate major composition (\%) & \\
$\quad$ Fixed carbon & $\leqq 85$ \\
$\quad$ Ash & $\leqq 13$ \\
$\quad$ Total sulfur & $\leqq 2.6$ \\
$\quad$ Volatile matter & $\leqq 1.0$ \\
$\quad$ Moisture & $2-4$ \\
Equivalent diameter of the coke particles $(\mathrm{cm})$ & 520 \\
Bulk density of the packing space $\left(\mathrm{kg} / \mathrm{m}^{3}\right)$ & 150 \\
Specific surface area of the packing space $\left(\mathrm{m}^{2} / \mathrm{m}^{3}\right)$ & 7.24 \\
pH & \\
\hline
\end{tabular}

As shown in Fig. 1, air from the blower was bubbled through an aqueous $\mathrm{NH}_{3}$ solution in a water-bathed Erlenmeyer flask to form an $\mathrm{NH}_{3}$-rich airstream. The concentration of the $\mathrm{NH}_{3}$ solution in the flask was maintained at a fixed level by constantly feeding and drawing the liquid. The ammonia concentration in the $\mathrm{NH}_{3}$-rich air could be varied by changing the concentration of the fed $\mathrm{NH}_{3}$ solution. The $\mathrm{NH}_{3}$-rich air was then mixed with a main airstream, which then flowed 
through the packing counter-currently with the recirculation liquid. The volume of recirculation liquid was kept in the system at $13 \mathrm{~L}$. The flow rates of the influent air and the recirculation liquid were verified by using rotameters and regulated by valves. Ports along the axial direction of the filter were provided for gas sampling.

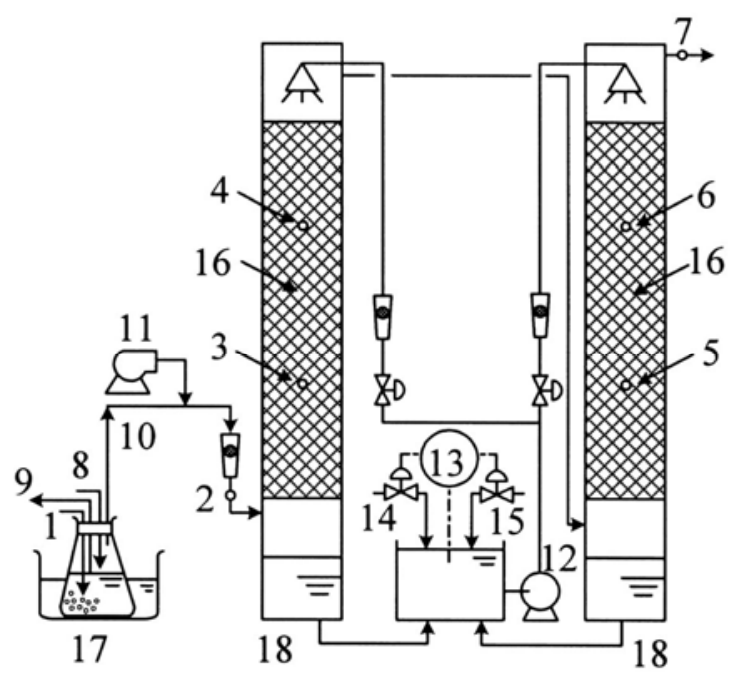

Fig. 1. Schematic diagram of the experimental system: (1) air, (2) influent, (3) sampling port $Z / H$ $=1 / 5$, (4) sampling port $Z / H=2 / 5$, (5) sampling port $Z / H=3 / 5$, (6) sampling port $Z / H=4 / 5$, (7) effluent, (8) $\mathrm{NH}_{3}$ solution, (9) wasted $\mathrm{NH}_{3}$ solution, (10) $\mathrm{NH}_{3}$-rich air, (11) fan, (12) recirculation pump, (13) $\mathrm{pH}$ controller, (14) $\mathrm{NaHCO}_{3}$ solution, (15) $\mathrm{HCl}$ solution, (16) coke packing, (17) water bath, (18) Biotrickling filter.

\section{Materials}

Glucose, $\mathrm{K}_{2} \mathrm{HPO}_{4}, \mathrm{NaHCO}_{3}$ and $\mathrm{HCl}$ were included in the recirculation liquid for microbial cultivation and acclimation. Glucose and $\mathrm{K}_{2} \mathrm{HPO}_{4}$ were carbon and phosphorous sources for microorganisms in the biofilm, respectively, and $\mathrm{NaHCO}_{3}$ and $\mathrm{HCl}$ were used as $\mathrm{pH}$ control and buffering agents for the recirculation liquid. Ammonia and all other nutrients were reagent-grade. Activated sludge with a mixed-liquor-suspended-solids (MLSS) concentration at around 5,500 $\mathrm{mg} / \mathrm{L}$ for seeding the filter was obtained from the wastewater plant of Grand Pacific Petrochemical CO., Kaohsiung, Taiwan. The sludge was adopted because it had exhibited that it can degrade almost all of the nitrogen-containing organics in the petrochemical wastewater to $\mathrm{CO}_{2}$ and nitrate. 


\section{Operation}

The operation sequence depicted in Table 2 was followed to determine the required start-up time and the long-term treatment stability, as well as the effects of volumetric loading $(L)$ and nutrient addition on the $\mathrm{NH}_{3}$ removal and nitrification efficiencies. A constant empty bed recirculation liquid velocity $\left(V_{\mathrm{L}}=Q_{\mathrm{L}} / A\right)$ of $3.82 \mathrm{~m}^{3} / \mathrm{m}^{2}$.h was maintained on days $1-177$. Three liters (on days 1-150) or $6 \mathrm{~L}$ (on days 151-187) of the recirculation liquid were replaced with the same volume of tap water on a daily basis to avoid the accumulation of metabolites such as nitrite and nitrate in the liquid.

In all the experimental phases, gas samples were collected at heights of $\mathrm{Z} / \mathrm{H}=0,1 / 5,2 / 5,3 / 5$, $4 / 5$ and 1 , and were analyzed for ammonia concentrations. Additionally, a recirculation liquid sample was taken to measure the contents of ammonia, nitrite, and nitrate at the time of liquid replacement. Besides days 122-128, the $\mathrm{pH}$ of the recirculation liquid was controlled at 6.5-6.8 by a $\mathrm{pH}$ controller (PC-310, SUNTEX, Taiwan).

Table 2. Operation sequence and conditions.

\begin{tabular}{|c|c|c|c|c|c|c|}
\hline $\begin{array}{c}\text { Phase } \\
\text { (1) }\end{array}$ & $\begin{array}{c}\text { Purpose } \\
\text { (2) }\end{array}$ & $\begin{array}{l}\text { Period } \\
\text { (day) } \\
\text { (3) }\end{array}$ & $\begin{array}{c}C_{0} \\
\text { (ppm) } \\
\text { (4) }\end{array}$ & $\begin{array}{c}U_{0} \\
(\mathrm{~m} / \mathrm{h}) \\
(5)\end{array}$ & $\begin{array}{c}L \\
\left(\mathrm{~g} / \mathrm{m}^{3} \cdot \mathrm{h}\right) \\
(6)\end{array}$ & $\begin{array}{l}\text { Nutrient* } \\
\text { (7) }\end{array}$ \\
\hline \multirow[t]{2}{*}{1} & Biofilm development and & $1-15$ & 0 & 38.2 & 0 & $\mathrm{a}$ \\
\hline & microbial acclimation & $16-40$ & $20-82$ & 38.2 & $0.22-0.58$ & $\mathrm{~b}$ \\
\hline \multirow[t]{2}{*}{2} & Effect of increasing volumetric & $41-54$ & $46-72$ & 76.4 & 1.14 & $\mathrm{~b}$ \\
\hline & ammonia loading & $55-72$ & $70-88$ & 114.6 & 2.04 & $\mathrm{~b}$ \\
\hline \multirow[t]{2}{*}{3} & Effect of no glucose & $73-90$ & $86-97$ & 152.8 & 3.18 & $\mathrm{C}$ \\
\hline & supplementation & $91-104$ & $130-260$ & 152.8 & 7.37 & C \\
\hline 4 & $\begin{array}{l}\text { Effects at the indicated high } \\
\text { volumetric ammonia loading }\end{array}$ & & & & & \\
\hline $4-1$ & No glucose supplementation & $105-121$ & $220-250$ & 248 & 13.1 & c \\
\hline $4-2$ & Decreasing $\mathrm{pH}$ from 6.5 to 6.0 & $122-128$ & $220-230$ & 248 & 13.1 & c \\
\hline $4-3$ & Glucose re-supplementation & $129-150$ & $200-245$ & 248 & 13.1 & $\mathrm{~b}$ \\
\hline $4-4$ & $\begin{array}{l}\text { Increasing replacement rate of } \\
\text { the recirculation liquid }\end{array}$ & $151-177$ & $210-245$ & 248 & 13.1 & $\mathrm{~b}$ \\
\hline $4-5$ & Recirculation liquid flow rate & $178-184$ & $225-240$ & 248 & 13.1 & $\mathrm{~b}$ \\
\hline $\begin{array}{l}{ }^{\mathrm{a}} \text { Gluco } \\
{ }^{\mathrm{b}} \text { Gluco } \\
{ }^{c} \text { Phosp }\end{array}$ & $\begin{array}{l}\text { se, } \mathrm{NH}_{4} \mathrm{Cl} \text {, and phosphate phosp } \\
\text { se and phosphate phosphorus } \\
\text { hate phosphorus }\end{array}$ & iorus & & & & \\
\hline
\end{tabular}

\section{Analytical}

Gas detection tubes (Gastec, USA) were used to measure ammonia content in gas samples. Ammonia-nitrogen of the recirculation liquid was analyzed by the Nesslerization method. Nitrite 
and nitrate of the recirculation liquid were analyzed using an ion chromatograph (Model Dionex100, Dionex Co., USA).

\section{RESULTS AND DISCUSSION}
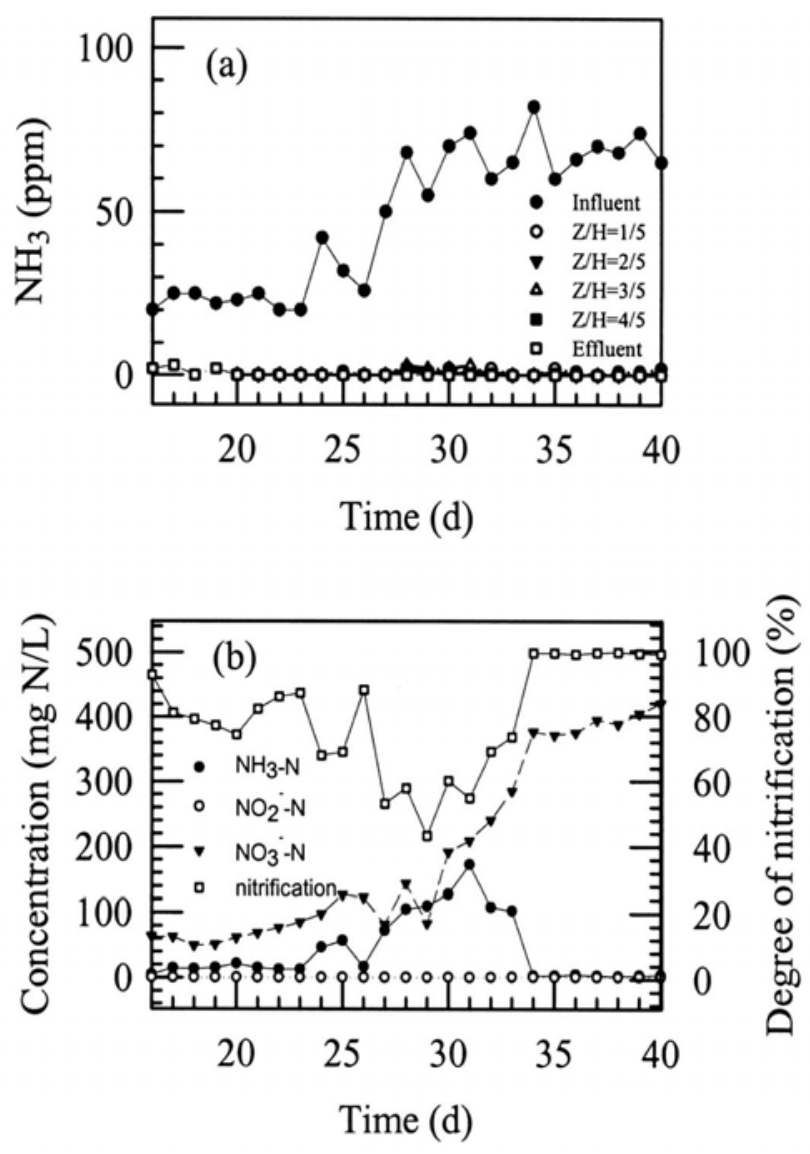

Fig. 2. Phase 1 experiment: (a) Time courses of ammonia concentration in gas streams, (b) Time courses of degree of nitrification of the absorbed ammonia and various $\mathrm{N}$ concentrations in the recirculation liquid.

\section{Microbial cultivation and acclimation}

Phase 1 began by filling the column with $7 \mathrm{~L}$ of tap water and $6 \mathrm{~L}$ of the seed-activated sludge (mixed liquor suspended solids $=5,500 \mathrm{mg} / \mathrm{L}$ ). For the first 15 days, $\mathrm{NH}_{4} \mathrm{Cl}$ and glucose were added to the recirculation liquid to provide readily available nitrogen and carbon sources, and thus enhance the growth of nitrifying bacteria in the biofilms. $\mathrm{NH}_{4} \mathrm{Cl}$ was then substituted by gaseous ammonia in the influent air to the biotrickling filters. Fig. 2(a) shows the time course of gaseous ammonia concentration at each packing height during the biofilm development and 
acclimation period. Experimental results indicate that almost all of the influent $\mathrm{NH}_{3}$ was eliminated at the fractional height of $Z / H=1 / 5$. By contrast, Fig. 2(b) shows that the development of biofilm for nitrification of the absorbed ammonia from the gas required 30 days.

\section{Effect of increasing volumetric ammonia loading}

In the Phase 2 experiment, the effects of increasing volumetric ammonia loading on the gaseous ammonia removal and degree of nitrification of the absorbed ammonia were tested by increasing the influent gaseous ammonia concentration (46-88 ppm) and the superficial gas velocity (76.4-115 m/h) through the column. Two volumetric ammonia loadings of 1.14 and 2.04 g $\mathrm{NH}_{3}-\mathrm{N} / \mathrm{m}^{3}$.h were tested. Fig. 3(a) shows the time variation of gaseous ammonia concentration at each packing height. The experimental results are similar to those observed in Phase 1 , in that almost all of the influent ammonia was absorbed at the height of $Z / H=1 / 5$.
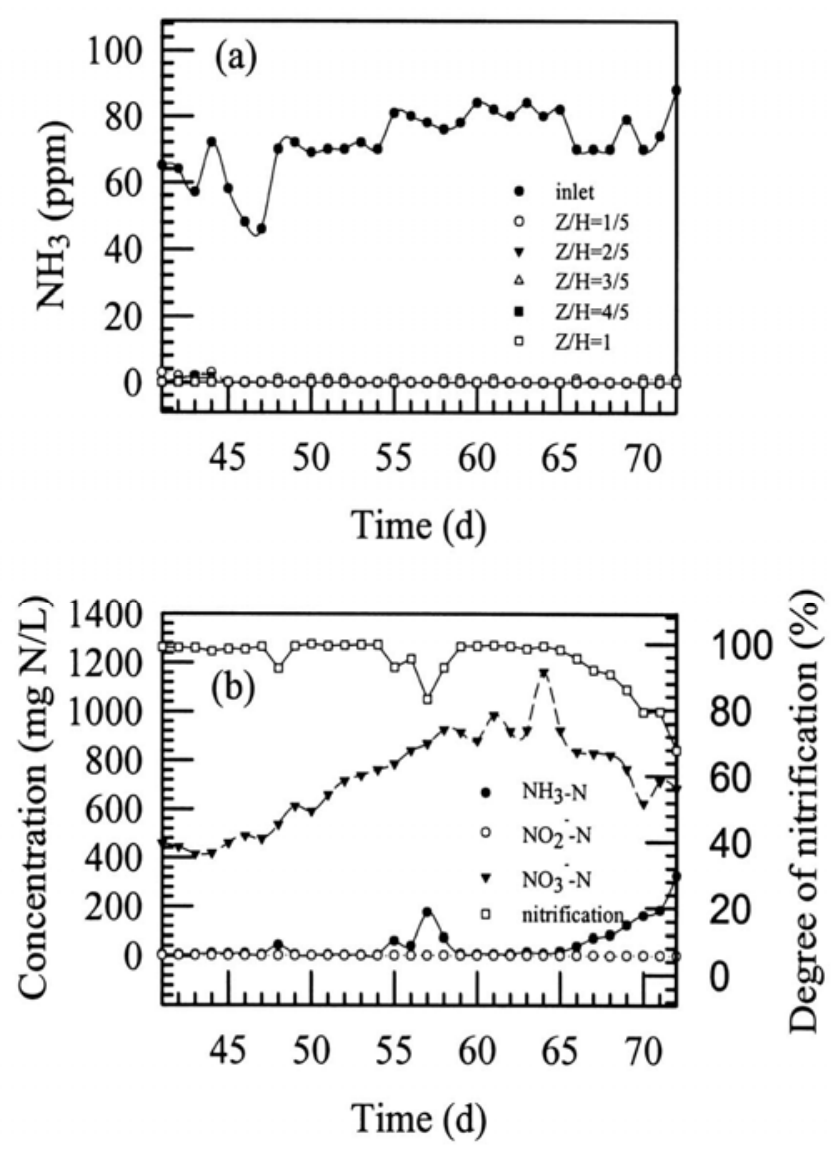

Fig. 3. Phase 2 experiment: (a) Time courses of ammonia concentration in gas streams, (b) Time courses for degree of nitrification of the absorbed ammonia and various $\mathrm{N}$ concentrations in the recirculation liquid. 
Fig. 3(b) demonstrates that the degree of nitrification of the absorbed ammonia was kept at a level of above 95\% until the 67th day. Figure 3(b) also shows $\mathrm{NO}_{3}{ }^{-} \mathrm{N}$ increased from 400 to 900 $\mathrm{mg} / \mathrm{L}$ in the period of 40-65 days due to the increasing ammonia loading to the filter (See: Phase 2 shown in Table 2) as well as the increasing nitrification capacity of the bacteria in the biofilms of the filter. After the day when the recirculation liquid temperature fell suddenly to $15^{\circ} \mathrm{C}$, due to a 3-day cold wave, the degree of nitrification declined gradually to $68 \%$ on the 72 nd day. Furthermore, gradual detachment of the biofilms from the packing surfaces resulted in an obvious increase in suspended solid concentration of the recirculation liquid during the low-temperature days. This finding, as well as a loss of microbial activity due to the lower system temperature, might help explain the drop in the nitrification capacity. Thereafter, the circulation tank was equipped with a heater and a temperature controller to maintain the recirculation liquid at $25 \pm$ $1^{\circ} \mathrm{C}$.

\section{Effect of no glucose addition}

Carbon, nitrogen, and phosphorus are essential nutrients for maintaining microbial activity for contaminant degradation. To test whether a nutrient deficiency would decrease the ammonia removal and nitrification efficiencies, no glucose was added to the system in Phase 3 experiment, while the volumetric ammonia loading was kept at 3.18 and $7.37 \mathrm{~g} \mathrm{NH}_{3}-\mathrm{N} / \mathrm{m}^{3}$.h for days 73-90 and 93-104, respectively. Fig. 4(a) shows the time variations of ammonia removal efficiencies. Experimental results indicate that in the whole period of around 21 days, the ammonia removal efficiencies could be maintained at a level of above 98\%, although it fell slightly at the higher loading of $7.37 \mathrm{~g} \mathrm{NH}_{3}-\mathrm{N} / \mathrm{m}^{3}$.h.

For nitrification, as indicated in Fig. 4(b), when $L=3.18 \mathrm{~g} \mathrm{NH}_{3}-\mathrm{N} / \mathrm{m}^{3}$.h, the nitrifying efficiency increased gradually from 22.6 to $90.0 \%$ in around 18 days, and the suspended solid concentration in the recirculation liquid decreased gradually in the same period. The careful control of the system temperature at a relatively stable value of around $25^{\circ} \mathrm{C}$ helped restore and maintain the microbial activity for ammonia nitrification. Moreover, with $L=7.37 \mathrm{~g} \mathrm{NH}_{3}-\mathrm{N} / \mathrm{m}^{3} . \mathrm{h}$, the nitrifying efficiency was also maintained in the range of 86.5 to $97.8 \%$. Nitrifying bacteria might be responsible for maintaining the fairly high nitrifying capacity for the 21 days with no supplemental carbon addition. 

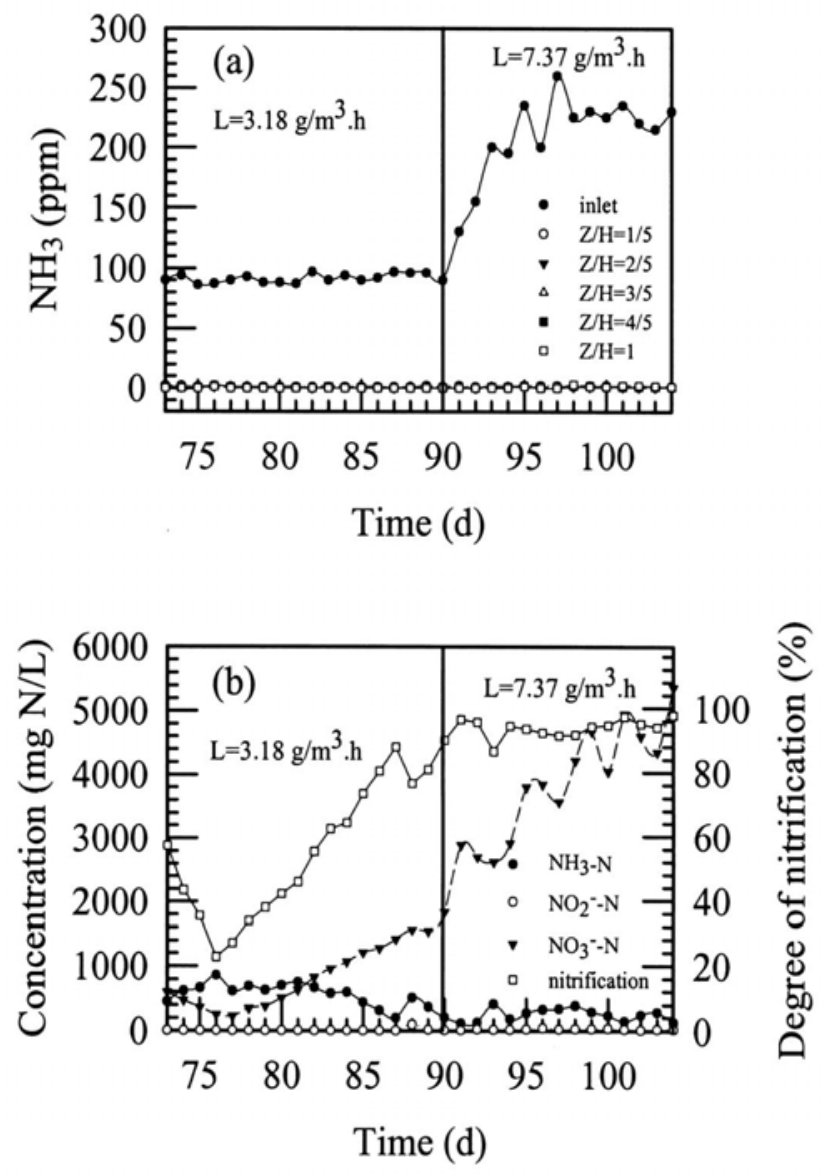

Fig. 4. Phase 3 experiment with no supplemental glucose to the recirculation liquid: (a) Time courses of ammonia concentration in gas streams with ammonia loadings 3.18 and $7.37 \mathrm{~g} \mathrm{NH}_{3^{-}}$ $\mathrm{N} / \mathrm{m}^{3}$.h, respectively, for days 73-90 and 93-104, (b) Time courses for degree of nitrification of the absorbed ammonia and various $\mathrm{N}$ concentrations in the recirculation liquid. Effects of high volumetric ammonia loading.

To determine the effect of high volumetric ammonia loading and $\mathrm{pH}$ of the recirculation liquid on the performance, tests were implemented at five stages of different carbon source addition, amount of liquid replacement and $\mathrm{pH}$ in the Phase 4 experiment. In all stages of this phase, the volumetric ammonia loading was kept at $13.1 \mathrm{~g} \mathrm{NH}_{3}-\mathrm{N} / \mathrm{m}^{3}$.h. Fig. 5 shows the experimental results which are discussed as follows.

\section{Phase 4-1: No glucose supplementation}

Glucose was not added to the replaced liquid in the Phase 4-1 experiment. The ammonia removal and nitrification efficiencies decreased from 99.6 to $96.6 \%$ and 97.8 to $39.4 \%$, respectively, in days 105-121 (Phase 4-1). The drop in nitrification could be attributed to a lack 
of carbon (glucose) source, or an accumulation of ammonium and nitrite ions in the recirculation liquid, which inhibited nitrification activity of the microorganisms therein.
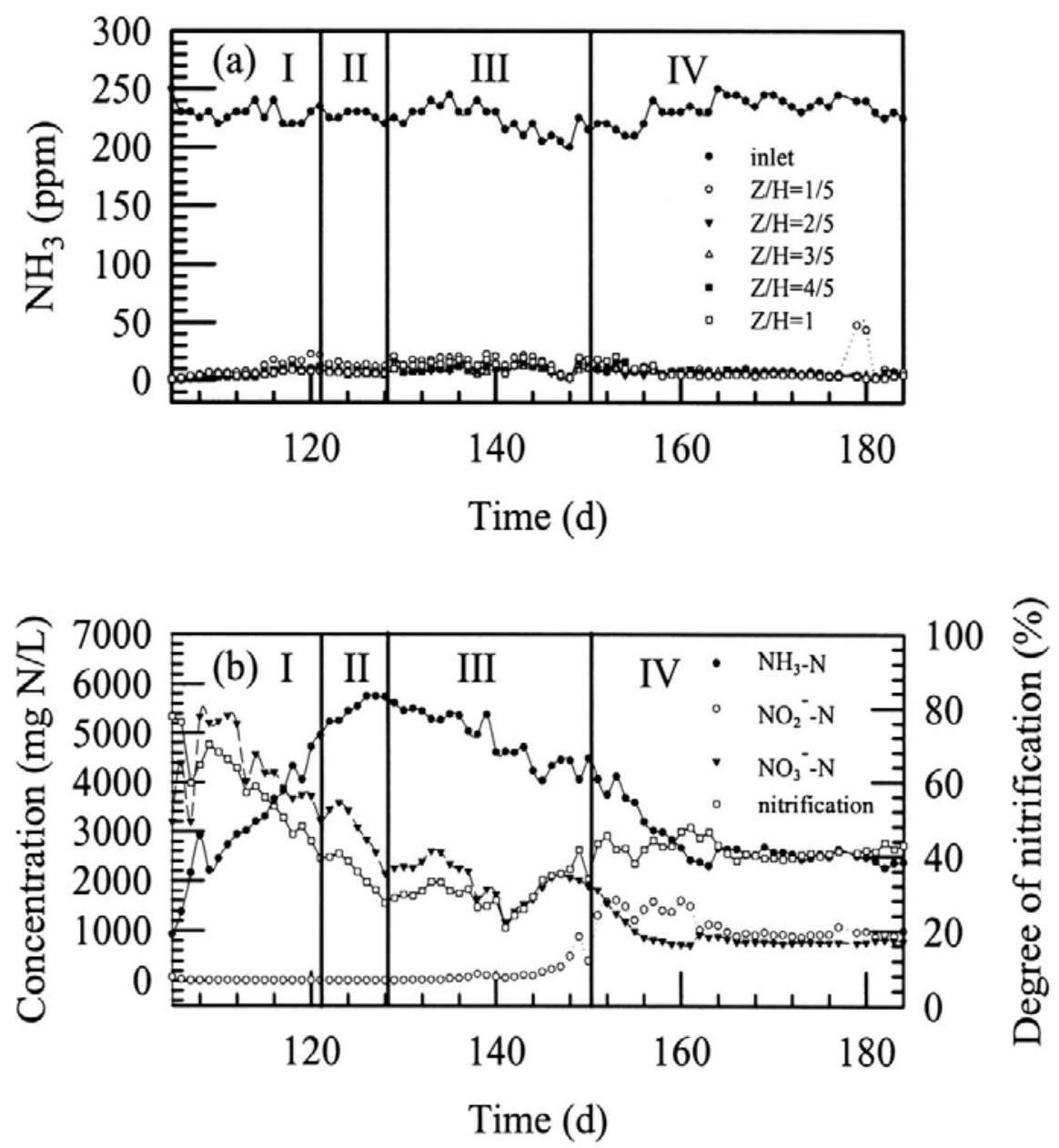

Fig. 5. Phase 4 experiment: (a) Time courses of ammonia concentration in gas streams, (b) Time courses for degree of nitrification of the absorbed ammonia and various $\mathrm{N}$ concentrations in the recirculation liquid. (I: Phase 4-1, II: Phase 4-2, III: Phase 4-3, IV: Phase 4-4.)

\section{Phase 4-2: Decreasing pH from 6.5 to 6.0}

Hartikainen et al. (1996) reported that inoculating a lab-scale peat biofilter with nitrifying activated sludge yielded a good ammonia nitrification capacity at $\mathrm{pH}=6.0$. The $\mathrm{pH}$ of the recirculation liquid was adjusted stepwise to 6.5, 6.3 and 6.0 to find the impact of $\mathrm{pH}$ on the ammonia absorption efficiency from the influent gas and to determine the consequent effects on the nitrification efficiency. Ammonia removal efficiency was improved slightly from 96.6 to 97.3\%. However, the degree of nitrification did not improve and it continuously dropped to 
28.3\%, possibly due to a lack of carbon, or the accumulation of ammonium and nitrate ions as discussed in the previous paragraph.

\section{Phase 4-3: Glucose re-supplementation}

The addition of glucose was revealed to enhance the adhesion of biofilms to the packing surfaces (Wu, 1996; Chou and Huang, 1997) and to enrich the heterotrophic nitrifying bacteria in the biofilms (Fang et al., 1993). To improve the nitrification, glucose was added again, with $\mathrm{C}: \mathrm{N}: \mathrm{P}$ ratios of 42:30:1 (Metcalf and Eddy, 1991) and 9:30:1 in days 129-140 and 141-150, respectively. In days 129 and 140, heterotrophic biofilms propagated rapidly on packing surfaces, and the biofilm color changed from grayish-white to yellowish-brown. The average ammonia removal efficiency was around $94.1 \%$. The nitrification peaked at $33.1 \%$, and then gradually decreased to $28.1 \%$. This phenomenon is probably due to a wide propagation of the heterotrophic bacteria, consuming a significant amount of dissolved oxygen for bio-oxidation of the added carbon, rather than nitrification of the ammonium ion in the recirculation liquid. To improve the nitrification, in days 141-150, the added glucose was reduced to the ratio $\mathrm{C}: \mathrm{N}: \mathrm{P}=9: 30: 1$. The nitrification rose from 20.9 to $41.7 \%$, with the ammonia removal efficiency kept at around $94.2 \%$. The nutrition ratio is close to the average ratio of $\mathrm{C}: \mathrm{N}: \mathrm{P}=7: 30: 1$ used in a biotrickling filter for the removal of air-borne NO (Chou and Lin, 2000).

\section{Phase 4-4: Increasing replacement rate of the recirculation liquid}

The inhibitory effects of ammonia and nitrous acid on nitrification were examined in this subphase. Nitrification inhibition was correlated with free ammonia and free nitrous acid concentrations. The free ammonia concentrations required for the inhibition of nitrosomonas and nitrobacters were found to be $10-150 \mathrm{mg} / \mathrm{L}$ and $0.1-1.0 \mathrm{mg} / \mathrm{L}$, respectively. Inhibition of nitrifying organisms by free nitrous acid was found to be initiated at concentrations 0.22-2.8 mg/L (Anthonisen et al., 1976). To lower the inhibition from the free ammonia and nitrous acid, the daily replacement of the recirculation liquid was raised from 3 to $6 \mathrm{~L}$, thus maintaining the ammonia removal and nitrification efficiencies at around $98 \%$ and $43 \%$, respectively, during days 151-184.

\section{Phase 4-5}

The recirculation liquid in biotrickling filters helps add nutrients, absorb gaseous contaminants, remove metabolite, moisten the biofilm and control the biofilm thickness. The effect of the liquid recirculation velocity $V_{\mathrm{L}}$ on the ammonia removal efficiency was tested during days 178-184. The biotrickling filter was operated at a constant $U_{0}$ of $248 \mathrm{~m} / \mathrm{h}$ and $V_{\mathrm{L}}$ of $0,0.95,1.90$, and 2.86 $\mathrm{m}^{3} / \mathrm{m}^{2} \mathrm{~h}$, with each $V_{\mathrm{L}}$ maintained for two days. Results shown in Fig. 6 indicate that with $V_{\mathrm{L}}$ kept at $1.90 \mathrm{~m}^{3} / \mathrm{m}^{2} \mathrm{~h}$, the ammonia removal efficiency was higher than $98 \%$ at $Z / H=1 / 5$. 


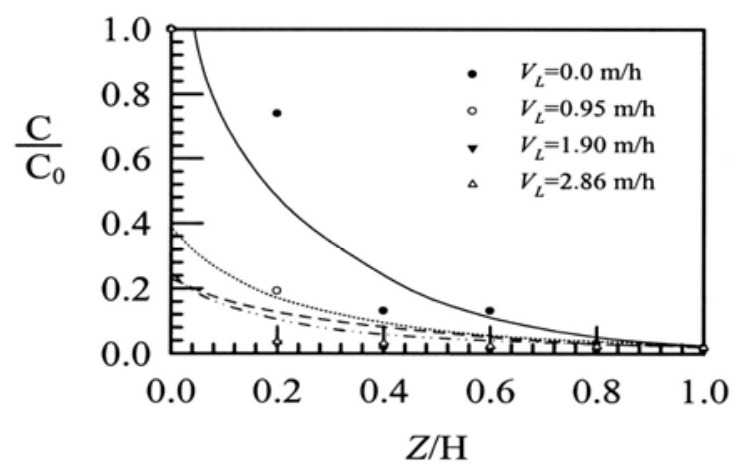

Fig. 6. Profiles of dimensionless ammonia concentration $\mathrm{C} / \mathrm{C}_{0}$ as a function of dimensionless packing height $Z / \mathrm{H}$ at $U_{0}=248 \mathrm{~m} / \mathrm{h}$ in Phase 4 experiment.

\section{Effects of EBRT on the ammonia removal efficiency}

The effects of gaseous EBRT of 3.93, 1.96, 1.31, 0.98, and 0.50 min on the ammonia removal efficiency were tested. As shown in Fig. 7, when EBRT $>0.98$ and 0.49 min, removal efficiencies of $>99 \%$ and $>96 \%$ were obtained, respectively.

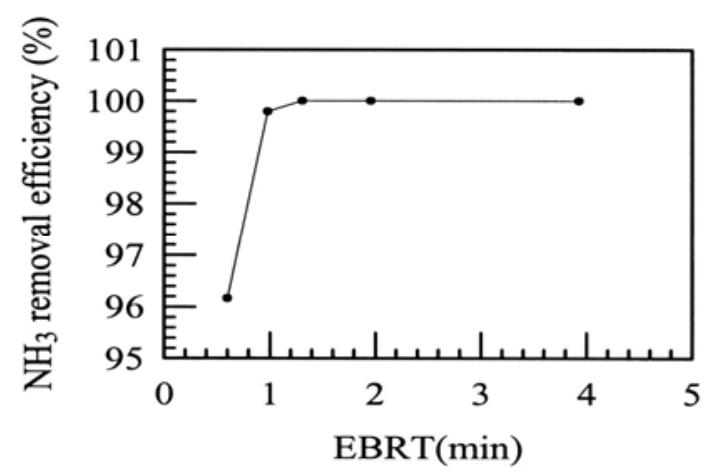

Fig. 7. Ammonia removal efficiency vs. gaseous EBRT in the biotrickling filter.

\section{Relationship between nitrification and volumetric loading}

As indicated in Fig. 8, nitrification above 94\% was obtained in long-term operation when the $\mathrm{pH}$ was controlled at 6.5-6.8 with $L<7.37 \mathrm{~g} \mathrm{NH}_{3}-\mathrm{N} / \mathrm{m}^{3}$.h. 


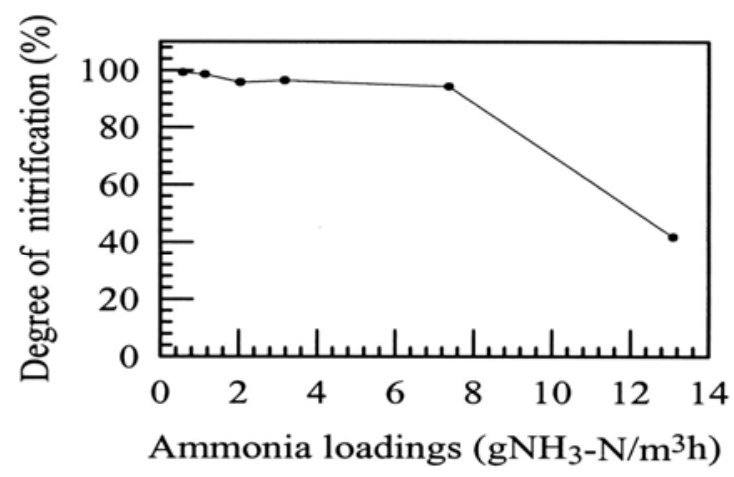

Fig. 8. Variation of degree of ammonia nitrification with ammonia loadings.

\section{Nitrogen balance}

Fig. 9 presents a comparison of cumulative nitrogen fed to the biotrickling filter from the influent gas and that leaving the filter in the experimental period of days 16-152. The mass of cumulative input ammonia-nitrogen is very close to that leaving the filter as the sum of ammonia$\mathrm{N}$ in the effluent gas and aqueous ammonia-, nitrite- and nitrate- $\mathrm{N}$ in the daily wasted liquors. As seen from Fig. 9, there is a good closure between the two cumulative values. In the 136 days, there was around a total of 1,560 $\mathrm{g} \mathrm{N}$ fed to and 1,440 $\mathrm{g} \mathrm{N}$ exited from the filter, the difference (120 g $\mathrm{N}$ or around $7.7 \%$ of the fed $\mathrm{N}$ ) might be converted into biomass.

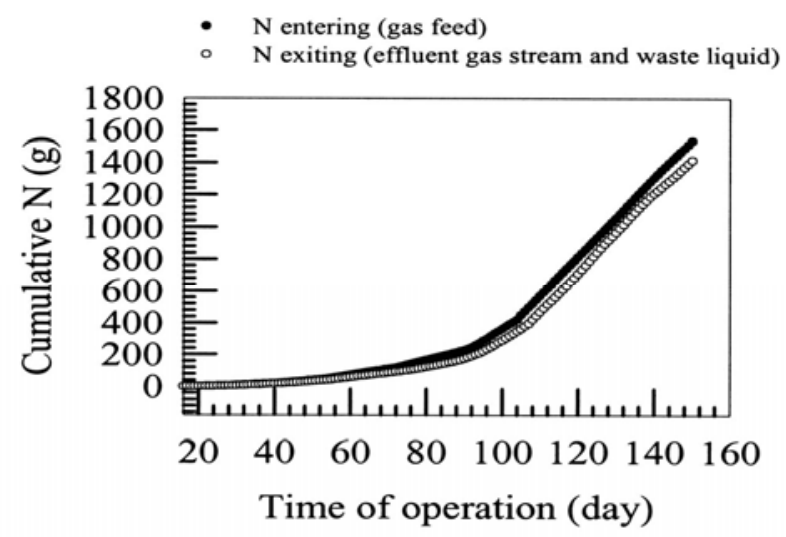

Fig. 9. Nitrogen balances for the biotrickling filter.

\section{CONCLUSIONS}

Several conclusions can be drawn from the experimental results.

First, coke with particle sizes $2-4 \mathrm{~cm}$ and a specific surface area of around $150 \mathrm{~m}^{2} / \mathrm{m}^{3}$ could be used as a packing material for gaseous ammonia removal in the experimental biotrickling filter. 
Biofilms for ammonia degradation can be developed in around 30 days by using activated sludge as microbial seed with operation parameters $U_{0}=38.2 \mathrm{~m} / \mathrm{h}, V_{\mathrm{L}}=3.82 \mathrm{~m} / \mathrm{h}$ and $L=0.22-0.58 \mathrm{~g}$ $\mathrm{NH}_{3}-\mathrm{N} / \mathrm{m}^{3} \cdot \mathrm{h}$.

Second, ammonia removal and nitrification efficiencies can be maintained at $98 \%$ and $94 \%$, respectively, for a period of around three weeks at $L=7.37 \mathrm{~g} \mathrm{NH}_{3}-\mathrm{N} / \mathrm{m}^{3}$.h, without addition of glucose or any other organic chemical. Without glucose supplementation, the biotrickling filter could reduce the operation cost for loadings of less than $7.37 \mathrm{~g} \mathrm{NH}$ - $\mathrm{N} / \mathrm{m}^{3}$.h with packing surfaces covered completely by biofilms.

Third, with $L=13.1 \mathrm{~g} \mathrm{NH}_{3}-\mathrm{N} / \mathrm{m}^{3} . h$ and no supplemental carbon, the ammonia removal and nitrification efficiencies decreased because of the detachment of biofilms from the packing surfaces and the accumulation of free ammonia and nitrous acid in the recirculation liquid which inhibited nitrification. The addition of an appropriate amount of glucose and increasing daily replacement of the recirculation liquid can enhance the ammonia removal efficiency and nitrification.

Finally, the removal efficiencies increase with increasing liquid recirculation rate in the investigated range. Removal efficiencies of $98 \%$ are obtained at $Z / H=1 / 5$ when $V_{\mathrm{L}}>1.90 \mathrm{~m} / \mathrm{h}$.

\section{NOMENCLATURES}

The following symbols are used in this paper:

$C_{0}=$ ammonia concentration in influent gas stream (ppm);

$\mathrm{EBRT}=$ empty bed gas retention time (sec);

$H=$ packing height $(\mathrm{m})$;

$L=$ volumetric ammonia loading $\left(\mathrm{g} / \mathrm{m}^{3} . \mathrm{h}\right)$;

$U_{0}=$ superficial gas velocity in packing section $(\mathrm{m} / \mathrm{h})$;

$V_{L}=$ liquid recirculation rate $\left(\mathrm{m}^{3} / \mathrm{m}^{2} . \mathrm{h}\right)$; and

$Z=$ packing height measured from gas influent end (m).

\section{REFERENCES}

Anthonisen, A.C., Loeher, R.C., Prakasam, T.B.S. and Srinath, E.G. (1976). Inhibition of Nitrification by Ammonia and Nitrous Acid. J. WPCF 48: 835-852.

Choi, J.H., Kim, Y.H., Joo, D.J., Choi, S.J., Ha, T.W., Lee, D.H., Park, I.H. and Jeong, Y.S. (2003). Removal of Ammonia by Biofilters: A Study with Flow-modified System and Kinetics. J. Air \& Waste Manage. Assoc. 53: 92-101.

Chou, M.S. and Huang, J.J. (1997). Treatment of Methylethylketone in an Air Stream by Biotrickling Filters. J. Envir. Engrg. ASCE 6: 569-576. 
Chou, M.S. and Lin, J.H. (2000). Biotrickling Filtration of Nitric Oxide. J. Air \& Waste Manage. Assoc. 50: 502-508.

Chung, Y.C., Huang, C. and Tseng, C.P. (1996). Reduction of $\mathrm{H}_{2} \mathrm{~S} / \mathrm{NH}_{3}$ Production from Pig Feces by Controlling Environmental Conditions. J. Environ. Sci. Health A31: 139-155.

Chung, Y.C., Huang, C. and Tseng, C.P. (2001). Biological Elimination of $\mathrm{H}_{2} \mathrm{~S}$ and $\mathrm{NH}_{3}$ from Wastegases by Biofilter Packed with Immobilized Heterotrophic Bacteria. Chemosphere 43: 1043-1050.

Chung, Y.C., Lin, Y.Y. and Tseng, C.P. (2004). Operational Characteristics of Effective Removal of $\mathrm{H}_{2} \mathrm{~S}$ and $\mathrm{NH}_{3}$ Waste Gases by Activated Carbon Biofilter. J. Air \& Waste Manage. Assoc. 54: 450-458.

Chung, Y.C., Lin, Y.Y. and Tseng, C.P. (2005). Removal of Hgh Concentration of $\mathrm{NH}_{3}$ and Coexistent $\mathrm{H}_{2} \mathrm{~S}$ by Biological Activated Carbon (BAC) Biotrickling Filter. Bioresour. Technol. 96: 1812-1820.

Don, J.A. and Feenstra, L. (1984). Odour Abatement Through Biofiltration. Proc., Symp. on Characterization and Control of Odoriferous Pollutants in Process Industries, Belgium.

Ergas, S.J., Schroeder, E.D. and Cheng, D.P.Y. (1993). Control of Air Emission of Dichloromethane, Trichloroethene, and Toluene by Biofiltration, in: Proc., 86th Annu. Meeting \& Exhibition of Air and Waste Mgmt. Assn., Paper No. 93-WA-52B.01, Denver, Colo.

Fang, H.Y., Chou, M.S. and Huang, C.W. (1993). Nitrification of Ammonia in Refinery Wastewater. Water Res. 27: 1761-1765.

Hartikainen, T., Ruuskanen, J., Vanhatalo, M. and Martikainen, P.J. (1996). Removal of Ammonia from Air by a Peat Biofilter. Environ. Technol. 17: 45-53.

Hartmans, S. and Tramper, J. (1991). Dichloromethane Removal from Waste Gases with a Trickle-bed Bioreactor. Bioprocess Engrg. 6: 83-92.

Jitendra, A.J., John, A.H., Robert, M.C., Peter, F.S. and Melvin, S.F. (2000). Biological Removal of Gaseous Ammonia in Biofilters: Space Travel and Earth-based Applications. J. Air \& Waste Manage. Assoc. 50: 1647-1654.

Liao, C.M., Chen, J.W. and Chen, S.C. (2004). Microbial Degradation of Livestock-generated Ammonia Using Biofilters at Typical Ambient Temperatures. J. Environ. Sci. Health B39: 185-198.

Lith, C.V., Ottengraf, S.P.P., Osinga, B. and Diks, R.M.M. (1993). The Biological Purification of a Multi-component Waste-gas Discharged in Artificial Glass Production, in: Proc., 86th Annu. Meeting \& Exhibition of Air and Waste Mgmt. Assn., Paper No. 93-WA-52B.07, Denver, Colo.

Malhautier, L., Garcian, C., Roux, J.C., Fanlo, J.L. and Cloirec, P.L. (2003). Biological Treatment Process of Air Loaded with an Ammonia and Hydrogen Sulfide Mixture. 
Chemosphere 50: 145-153.

Metcalf and Eddy (1991). Wastewater Engineering: Treatment, Disposal, Reuse, third ed., McGraw-Hill, New York.

Mohamad, Y., Mitsuyo, H. and Makoto, S. (1998). Removal Kinetics of Ammonia by Peat Biofilter Seeded with Night Soil Sludge. J. Ferment. Bioeng. 85: 502-506.

Ottengraf, S.P.P. (1986). In: Biotechnology--Exhaust Gas Purification, Rehm H.J. and Reed G. (Eds.), VCH Verlagsgesellschaft, Weinheim, Germany, p.425.

Scholtens, R., Klarenbeek, J.V. and Bruins, M.A. (1987). In: Volatile Emissions from Livestock Farming and Sewage Operations--Control of Ammonia Emissions with Biofilters and Bioscrubbers, Nielsen, V.C., Voorburg, J.H., L`Hermite P. (Eds.), New York, p.196.

Togna, A.P. and Folsom, B.R. (1992). Removal of Styrene from Air Using Bench-scale Biofilter and Biotrickling Filter Reactors, in: Proc., 85th Annu. Meeting \& Exhibition of Air and Waste Mgmt. Assn., Paper No. 92-116.04, Kansas City, Mo.

Togna, A.P. and Singh, M. (1994). Biological Vapor-phase Treatment Using Biofilter and Biotrickling Filter Reactors: Practical Operation Regimes. Environ. Prog. 13: 94-97.

Wu, F.L. (1996). Performance Study on the Treatment of Toluene in an Air Stream by Biotrickling Filters. Master Thesis, Inst. of Envir. Engrg., Nat. Sun-Yat Sen Univ., Kaoshiung, Taiwan, ROC, 24.

Received for review, September 18, 2006 Accepted, November 14, 2006 